\title{
The Implementation of Management North Sumatera Wushu 2017
}

\author{
Tengku Imam Buana \\ Department of Sport Education \\ Post Graduate School, State University of Medan \\ Medan, North Sumatera, Indonesia \\ Tengkuimam@gmail.com
}

\begin{abstract}
This research aims to know the training program, the quality of the coaches, the circumstances of the organization, the facilities and infrastructure, and the funds used in North Sumatera wushu development. This research used descriptive qualitative method with sample of North Sumatera Wushu provincial officials. Data collections were observation, interview, and documentations. To data sources were officials, coaches, and athletes of North Sumatera wushu. The documents or substantiations used to prove the data were charters, photos, management structure and others. The results of this research concerned were: (1) The development of wushu athletes of North Sumatera achievement was very good, (2) The organizational management was friendly, opennes among others and made the things run well (3) The quality of coaches were excellent and competedt in training. The conclusions obtained in the wushu development of North Sumatera were: (1) the wushu development of North Sumatera should be an icon of sports development model in North Sumatera, supported by the good function of the management, can reach the set target, (2) Having a complex organizational structure in line with the work programs and responsibilities, (3) Having the International and National competence and supported by the complete facilities and infrastructures.
\end{abstract}

\section{Keywords-component; Management; Wushu; North} Sumatera

\section{INTRODUCTION}

Sports achievement of a nation is a state asset that can boast and awaken the soul of nationalism of a nation. Sports achievement is also one of the nation's progress. Therefore the competition achieves sports achievement among countries continues to run with various developments in sports science and sports technology. Sports achievements are not only determined by the athlete's seeds but also must be supported by sport science, sport management is applied to achieve good achievement. Nurasjati (2013:87) argues that "sports management in Indonesia is still not fully implemented and it is a weak point in the development of sports nationally. Management is not just management, but further down to the base is the Indonesian view of the sport" [6].

Barbu and Craciun (2012:60) "In terms of management, the manager who acts in the spirit of this theory will seek to obtain long term profit by making judicious and documented decisions" [2]. Organizing management in sports play an important role, with the right settings and managements then the achievement will be achieved well. All elements that exist in supporting these sports achievements must be mutually supportive and mutually sustainable. Achievement of sports in Indonesia during this indeed happened ups and downs in achievement. It can be seen in several sport events both the SEA Games, the ASEAN Games and other world championships. To be able to compete with countries that have great achievements in the field of sports, it takes a quality of management. Ups and downs of a sport achievement one of which is influenced by organizational management and coach management. The management should also be supported by other factors such as fund, leader, human resources, facilities and infrastructures, and other sources.

One of the sports that became the mainstay of North Sumatera is the sport of Wushu. At the National Sports Week XIX championship of West Java. Achievements of Wushu North Sumatra is ranked first. This appears in the following data:

TABLE I MEDALS RESULTED OF WUSHU IN NATIONAL SPORTS WEEK XIX WEST JAVA

\begin{tabular}{|c|c|c|c|c|c|}
\hline Rank. & Province & Gold & Silver & Bronze & Total \\
\hline 1 & North Sumatera & 8 & 9 & 4 & 21 \\
\hline 2 & Jakarta & 6 & 1 & 5 & 12 \\
\hline 3 & West java & 4 & 2 & 6 & 12 \\
\hline 4 & East Java & 2 & 5 & 3 & 10 \\
\hline 5 & Central Java & 2 & 3 & 5 & 10 \\
\hline 6 & Yogyakarta & 1 & 1 & 1 & 3 \\
\hline 7 & Jambi & 0 & 1 & 3 & 4 \\
\hline 8 & South Borneo & 0 & 1 & 0 & 1 \\
\hline 9 & Banten & 0 & 0 & 2 & 2 \\
\hline 9 & North Borneo & 0 & 0 & 2 & 2 \\
\hline 11 & East Borneo & 0 & 0 & 1 & 1 \\
\hline 11 & West Nusa Tenggara & 0 & 0 & 1 & 1 \\
\hline 11 & Papua & 0 & 0 & 1 & 1 \\
\hline \multicolumn{2}{|r|}{ Total } & 23 & 23 & 34 & 80 \\
\hline
\end{tabular}

At the National Sports Week XIX of West Java, North Sumatera Wushu's team has won 21 medals. The medals were 8 gold, 9 silver, and 4 bronze. Certainly the medals 
were achieved by Wushu's team of North Sumatera gave a very big contribution to the rank of North Sumatera at the National Sports Week XIX Championship of West Java. North Sumatra Wushu is one of the benchmarks of Indonesia Wushu coaching. North Sumatera Wushu has good potential of athletes for Taulo although Sanda category which have outstanding achievements in national championship as well as International level. Of course these achievements make Wushu as a sport that became the mainstay of North Sumatera

TABLE II DATA OF WUSHU ATHLETES OF NORTH

SUMATERA WHO OBTAINED MEDALS AT

NATIONAL SPORTS WEEK XIX WEST JAVA

\begin{tabular}{|c|c|c|c|}
\hline Category & Name & Class & Medal \\
\hline Changquan & Aldi Lukman & Taulo Putra & Bronze \\
\hline Changquan & Charles Sutanto & Taulo Putra & Bronze \\
\hline Nanquan + Nangun & Har ris Horatius & Taulo Putra & Gold \\
\hline Nanquan + Nangun & Erik Losardi & Taulo Putra & Silver \\
\hline Jianshu + Qiangshu & Wilbert Sanjaya & Taulo Putra & Silver \\
\hline Jianshu + Qiangshu & Charles Sutanto & Taulo Putra & Bronze \\
\hline Daoshu + Gunshu & Jodis & Taulo Putra & Silver \\
\hline \multirow{3}{*}{ Duillian } & Jodis & \multirow{3}{*}{ Taulo Putra } & \multirow{3}{*}{ Gold } \\
\hline & Erik Losardi & & \\
\hline & Charles Sutanto & & \\
\hline Nanquan + Nandao & Juwita Niza W. & Taulo Putri & Gold \\
\hline Taijijian + taijiquan & Lindswell Kwok & Taulo Putri & Gold \\
\hline \multirow{2}{*}{ Duillian } & Dessy Indri A. & \multirow{2}{*}{ Taulo Putri } & \multirow{2}{*}{ Silver } \\
\hline & Dwi Amphibi & & \\
\hline $48 \mathrm{Kg}$ & Franstitus Hamdani T. & Sanda Putra & Bronze \\
\hline $52 \mathrm{Kg}$ & Dasman Tua Simbolon & Sanda Putra & Gold \\
\hline $65 \mathrm{Kg}$ & Hendrik Tarigan & Sanda Putra & Gold \\
\hline $48 \mathrm{Kg}$ & Junita Malau & Sanda Putri & Gold \\
\hline $56 \mathrm{Kg}$ & Mei Yulia Ningsih & Sanda Putri & Gold \\
\hline $60 \mathrm{Kg}$ & Elika BrTarigan & Sanda Putri & Silver \\
\hline
\end{tabular}

The success achieved by the North Sumatera Wushu's team at the National Sports Week XIX championship of West Java must be the pride of the people of North Sumatera.

The success of the development of North Sumatera sport achievement certainly cannot be separated from good management in its management. As proposed by Ricky W. Griffin (2000:148) "to be able to run good management needs to be supported by management governance that includes planning, organizing, controlling human resources. In performing coaching of achievement certainly require people who have competent in management" [3].
Achievements can be achieved because of good sports development and have good management as well as sports management, then development of athletes, coaches, facilities and infrastructures management, organizing events in cooperation with relevant institutions can be realized as expected. Moving from the reality of data, theories, obtained from the author of relevant sources, then the author intend to deepen research on The Implementation of Management North Sumatera Wushu 2017.

The development of achievement is a process of talent development and potential athletes by following selection, championship, following the competition on a higher level regularly, directed, and sustainable. It will produce highperforming athletes and so on until produce reliable athletes.

The maximum sports achievement can be achieved with a good and correct development. As a whole, achievement is a combination of physical condition, mental ability, mastery of technique, tactical skills, among which through the development of training program to achieve peak performance. Regular, systematic, programmed and continuous guidance with IPTEK shortcuts applied in the training program can improve the quality of its ability.

Regular, systematic, programmed and continuous development with science and technology approach is applied in the training program can improve the quality of athletes' ability.

The implementation of the development done by North Sumatera Wushu provincial officials as a whole is very well done. Supported by athletes who have high motivation to keep achieving the glorious achievement and the name of the nation.

\section{A. Management of an Organization}

North Sumatera Wushu provincial officials have a competent structure, with the composition of personnel who have tasks, responsibilities, and programmed functionary positions. They are the patron, founder, advisor, general chairman, daily chairman, deputy general chairman I, deputy general chairman II, general secretary, deputy general secretary, treasurer, deputy treasurer, head of regional organization, deputy head of regional organization, head of section achievement development, deputy head of section achievement development, section of funding and effort, head of section research and development, deputy head of section research and development, health sector, technical commission, public relations and documentation sector. Each functionaries have a position, work program and responsibility.

Overall, the management of an organization which is formed in North Sumatera Wushu provincial officials fulfill the needs that are in it and run well in appropriate with the characteristics of a good organization. As stated by Harsuki that "the success of administration and management in carrying out its organizational function can be judged from its ability to create a good organization, a good organization is the obvious purpose of organization, the unity of direction, the division of task, the unity of authority and 
responsibility, and organizational goals must be understood by everyone in the organization" [3]. As described in the Constitution of the Sports System (UUD) of 2005 No. 3 in article 40 on sports management that "the staffs of the national sports committee, the provincial sports committee and the kabupaten or city sports committee are independent and not bound by structural and public office activities" [7].

\section{B. Coach}

The coach owned by North Sumatera provincial officials is a coach who has very good experience and Wushu science coaching classified. The Coaching is conducted by North Sumatra provincial officials is divided into two namely junior and senior for Taulo and Sanda. Training done by trainers for the classs of Wushu Taulo is maximal due to the training schedule given by the coach from Monday to Sunday or can be said every day of practice. But on Tuesday and Thursday the exercise is done half a day. For the training site, the trainer provides program at Kusuma Wushu Indonesia Foundation which is the training center of Wushu of North Sumatera Province.

The Taulo coach in North Sumatera provincial officials for Sea Games and International or World Championship. North Sumatera provincial officials to foster and produce outstanding achievements using one foreign coach and one national coach. And for the national coach is two peoples with two assistant coaches. For junior level training the trainers are assisted by senior athletes to conduct the training.

While for the class of Sanda the training set by the coach is not much different than Wushu Taulo, there are training schedule everyday given by the coach, only in the class of Wushu Sanda, the coach does not provide training schedule on Sunday. And for the training site, the coach uses several training places such as Ocean's sport centre, UNIMED Stadium, and Kusuma Wushu Indonesia Foundation. For the number of coach Wushu Sanda in Wushu North Sumatra provincial officials using two foreign coaches and three national coaches.

\section{Achievement Development}

Based on the results of the author's research that the achievement development in North Sumatera Wushu provincial officials is very good, supported with a good functions and management and in appropriate with existing indicators, fully perfect to achieve the target in the program even though no sponsors, but has adequate facilities and infrastructure. The achievement development of North Sumatra Wushu provincial officals does not involve many peoples, but the nursery starts from early age only for calss of Wushu Taulo, while for class of Sanda is no nursery. Athletes who got the opportunity to practice in North Sumatera provincial officials is the monitoring result of regional championship that implemented. But the effort to achieve the achievement remains well done and programmed.

\section{Training Program}

The training programs implement at the achievement development Wushu North Sumatera provincial officials is very good, so the program runs as planned. As mentioned by Rusli Lutan, "the planning of the training program is the phasing of the training activity, which is in the preparatory phase which prioritizes the physical condition of the preparation rather than improving the technique skill and strategy. Preparation of the training program includes specific of physical conditions, pre-competition and competition" [4].

\section{E. Facilities and Infrastructures}

Wushu North Sumatra provincial officials assisted by the government to have the adequate and complete of facilities and infrastructures has been done. Surely this makes the athletes are very flexible and maximal in doing the training. As stated in UU RI No.3 year 2005 on the national sports system, in article 1 verse 20 and $\mathbf{J} 21$ it is explained that "facility is equipment and supplies are used for sports activities. Sport infrastructure is a place or space including the environment used for sport activities and sport organizers" [7]. The central and regional governments also play a role in assisting and providing then supplementing the facilities and infrastructures. Central and local government are responsible for the maintenance, facilities and infrastructures development of POPPROV, POPWIL, PON, and other events that are used for the benefit of sport achievement development by KONI Provincial and main of the sports organization. And Wushu North Sumatera provincial officials and the government have completed these facilities and infrastructures.

\section{F. Funding}

Funding of Wushu North Sumatra provincial officials in the can of cooperation between the general chairman and KONI. North Sumatra provincial officials provides development by providing the coach and athletes of the mess as a place to live, transportation, consumption costs, and honorarium. While training equipment fund for national and international championships are financed by local and national governments. For funding and financing of athletes who follow regional and national championships are financed by local government whereas the athletes who follow the International championships such as Sea Games, Asian Games funding and financing by the central government. This is appropriate with UU RI No. 32005 Article 69 verse 1 and 2 explain "sports funding is a shared responsibility between the government and the people. The central government and region governments must allocate sports funding through APBN and APBD.

\section{METHOD}

The method used is descriptive qualitative. Descriptive method is a method in the status of a human group, an object, a state, a system, or a situation at now (Nazir, 1985:63) [5]. Descriptive method to create descriptive, picture or portrait systematically, factual and accurate to the 
facts, and the relationship between the phenomena investigated. While qualitative is the data described with words or sentences are separated by category to obtain conclusions (Arikunto, 1998:245) [1].

\section{RESULTS AND DISCUSSION}

The conclusions obtained in the wushu development of North Sumatera were: (1) the wushu development of North Sumatera should be an icon of sports development model in North Sumatera, supported by the good function of the management, can reach the set target, (2) Having a complex organizational structure in line with the work programs and responsibilities, (3) Having the International and National competence and supported by the complete facilities and infrastructures

\section{CONCLUSION}

The achievement development made by Wushu North Sumatra provincial officials is done very well and competently, it can be seen from planning, organizing, directing, and supervising in appropriate with the procedure. It should be the management owned by Wushu North
Sumatra provincial officials become an icon model for other sports in sport development to achieve a brilliant achievement, especially in North Sumatera

\section{REFERENCES}

[1]. Arikunto. Suharsimi. "Prosedur Penelitian Suatu Pendekatan Praktek", Jakarta: PT. RinekaCipta, 1998

[2]. Barbu. M.C.R and Liviu Craciun, "Considerations On Managerial Ethics in Sports Organizations", Volume X. issue 1/2012, pp 59-68, in press

[3]. Griffin. Ricky W, "Sport Sociology, 3rd Edition Dubuque IOWA: Kendalhunt Publishing Company, 1992

[4]. Harsuki, "Perkembangan Olahraga Terkini Kajian Para Pakar", Jakarta: PT. RajaGrafindo Persada, 2003

[5]. Lutan. Rusli, "Pembaruan Pendidikan Jasmani di Indonesia". Depdiknas, 2001

[6]. Nazir. Mohammad, "Metode Penelitian". Bandung: Grafika Indonesia., 1985

[7]. Nurasjati. Nurosi, "Dimensi Sosiologi dalam Manajemen Olahraga di Indonesia", Jakarta: Journal of Sport IPTEK, 2013

[8]. UU RI No. 3 Year 2005, "Sistem Keolahragaan Indonesia", RI: Ministry of Youth and Sports 